\title{
Biochemical Analysis by Calcium Determination on the Newly Formed Bone in Critical Bone Defects Submitted to Different Treatments. A Pilot Study
}

\author{
Análisis Bioquímico para la Determinación de Calcio en Hueso Neoformado con Defectos Críticos \\ Sometidos a Diferentes Tratamientos. Estudio Piloto

\begin{abstract}
"João Paulo Mardegan Issa; **Sérgio Olavo Petenusci; "*Selma Siéssere; *"Simone Cecílio Hallak Regalo;
***Ruberval Armando Lopes; **Miguel Angel Sala Di Matteo; ${ }^{* *}$ Mamie Mizusaki Iyomasa \& ***Helton Luiz Aparecido Defino
\end{abstract}

ISSA, M. J. P.; PETENUSCI, S. O.; SIÉSSERE, S.; REGALO, H. S. C.; LOPES, A. R.; DI MATTEO, S. M. A.; IYOMASA, M. M. \& DEFINO, A. H. L. Biochemical analysis by calcium determination on the newly formed bone in critical bone defects submitted to different treatments. A pilot study. Int. J. Morphol., 25(3):511-518, 2007.

SUMMARY: The aim of this study was to evaluate the calcium dosage of the newly formed bone, in critical bone defects created on the calvarial tissue and filled by different substances, in male Wistar rats. A cylindrical critical bone defect (6x $2 \mathrm{~mm})$ was created in the posterior portion, left side, on the calvarial bone in nine animals and filled with: animals' coagulum, monoolein gel, poloxamer gel, monoolein gel $+1 \mu \mathrm{g}$ rhBMP-2, monoolein gel $+3 \mu \mathrm{g}$ rhBMP-2, monoolein gel $+7 \mu \mathrm{g}$ rhBMP-2, poloxamer gel $+1 \mu \mathrm{g}$ rhBMP-2, poloxamer gel $+3 \mu \mathrm{g}$ rhBMP-2, poloxamer gel $+7 \mu \mathrm{g}$ rhBMP- 2 . The results of this study showed a positive correlation between the calcium dosage analysis and the newly formed bone.

KEY WORDS: Bone repair; Biomaterials; rhBMP-2; Carriers; Calcium.

\section{INTRODUCTION}

Osteogenic factors, and particularly members of the transforming growth factor (TGF-) superfamily, play a key role in bone formation and repair (Wozney and Rosen, 1998). BMP-2, as the prototype of the bone morphogenetic proteins, induces bone regeneration and ectopic bone formation in adult vertebrates (Reddi, 1997, 1998) and determines important steps during early embryogenesis and limb/wing development in animals (Hogan, 1996). Accordingly, BMP2 and its close relative BMP-4 have been studied intensively in developmental biology, and these proteins are of interest for therapeutic applications. Although the protein is usually supplemented to the medium in a soluble form in vitro, there are constraints for sustained delivery due to the need to provide bioactive protein for an extended period of time in vivo. An ideal osteoinductive carrier for bone morphogenetic protein-2 (BMP-2) delivery should consist of a biomaterial that is able to deliver protein over the required physiological timeframe, without compromising the biological activity of the molecule or the surrounding tissue upon release. In addition, the scaffolds should biodegrade at a rate commensurate with new extracellular matrix production and be biocompatible.

Different biomaterials have been used as BMP-2 delivery systems in ectopic bone formation: poly $(\mathrm{D}, \mathrm{L}-$ lactide) disks (Winn et al., 1999) poly(D,[SCAP]L-lactideco-glycolide) (PLGA) porous scaffolds(Whang et al. 1998) and microparticles entrapped inside calcium-phosphate cement disks (Ruhe et al., 2003), collagen in the form of sponges (Winn et al.; Uludag et al., 1999 and Uludag et al., 2001) and gels (Kim \& Valentini, 2002), deorganified bovine bone particles (Winn et al.), honeycomb-shaped hydroxyapatite (Kuboki et al., 2001) and bioglass in the form of fibers (Mahmood et al., 2001). Additionally, hyaluronic acid scaffolds loaded with BMP-2 induced differentiation of the multipotent cell line C3H10T1/2 (Kim \& Valentini). Delivery of BMP-2 has been extensively studied because of its importance in cellular differentiation. Delivery systems

\footnotetext{
* Graduate student, Faculty of Dentistry, University of São Paulo, Ribeirão Preto, São Paulo, Brazil.

** Professor, Faculty of Dentistry, University of São Paulo, Ribeirão Preto, São Paulo, Brazil.

${ }^{* * * *}$ Professor, Faculty of Medicine, University of São Paulo, Ribeirão Preto, São Paulo, Brazil.
} 
ISSA, M. J. P.; PETENUSCI, S. O.; SIÉSSERE, S.; REGALO, H. S. C.; LOPES, A. R.; DI MATTEO, S. M. A.; IYOMASA, M. M. \& DEFINO, A. H. L. Biochemical analysis by calcium determination on the newly formed bone in critical bone defects submitted to different treatments. A pilot study. Int. J. Morphol., 25(3):511-518, 2007.

for other morphogens or cytokines in vitro and in vivo include poly(D,L-lactide), collagen sponges for BMP-4 and BMP-6 (Uludag et al., 1999), collagen for BMP-7 (Rutherford \& Gu, 2000), polyesterurethane for a cocktail containing boneinducing BMPs (Saad et al., 2000), poly(propylene fumarate) for TGF-ß1 (Vehof et al., 2002). PLGA porous scaffolds for osteoblast stimulating factor-1 (Yang et al., 2003) and tricalcium phosphate and glass-ceramic and PLGA/glassceramic composites and human bone for BMP-4, basic fibroblast growth factor (FGF-2), and vascular endothelial growth factor (VEGF) (Ziegler et al., 2002). In all cases, a broader set of biomaterial functional features and control of release profiles of the morphogens or cytokines would be important attributes to expand the benefits of these systems.

Monoolein is a biodegradable polar lipid that has no marked toxic effects (Ganem-Quintanar et al., 2000). Depending on water content and temperature, several phases can be formed, including reverse cubic and hexagonal phases. The reverse cubic phase of monoolein and water is formed at room temperature, and has been shown to accommodate and sustain the release of drugs with various physical chemical properties, including proteins and peptides (Lee \& Kellaway, 2000 a, b; Lara et al., 2005 and Turchiello et al., 2003).

Chitosan is a linear cationic polysaccharide prepared from chitin, found in shells of shrimps, lobsters and crabs. Chitosan consists of $N$-acetyl glucosamine and is classified according to the degree of deacetylation (DDA) (Hejazi \& Amiji, 2003). It presents biocompatibility and degradation in biological medium as well as interact with some mucosal membrane due to presents positive charges in physiological pH (Mi et al., 2002).

Poloxamers are non-ionic polyoxyethylenepolyoxypropilene-polyoxiethylene $\left(\mathrm{PEO}_{n}-\mathrm{PPO}_{n}-\mathrm{PEO}_{n}\right)$ triblock copolymers with many pharmaceutical applications. Poloxamer 407 (P407), which has a molecular weight of 12,000 Daltons and a PEO/PPO ratio of 2:1 by weight, has been the most widely used of these copolymers. Solutions of P407 at concentrations of $20 \%$ show in situ thermoreversible gelation behavior (Schmolka, 1972; Bohorquez et al., 1999; Moore et al., 2000), which permit them to be administrated in cold liquid form by syringe. After administration, P407 cold solution forms a gel in situ at the site of the injection. The P407 gel is biocompatible with cells and body fluids (Park \& Park, 1996). Used in pharmaceutical preparations, its low toxicity and weak immunogenic properties make it a suitable vehicle for drug delivery (Johnston and Miller, 1985; Veyries et al., 1999 and Paavola et al.).

The aim of this study was to evaluate the calcium dosage of the newly formed bone, in critical bone defects created on the calvarial tissue and filled by different substances, in male Wistar rats.

\section{MATERIAL AND METHOD}

This study followed the requirements of the Ethics Committee on the Use of Animals in Experimentation at the University of São Paulo, Brazil.

Substances. The recombinant human bone morphogenetic protein, type 2 (rhBMP-2) used in this study was obtained at Theodor-Boveri-Institut für Biowissenschaften, Am Hubland, Würzburg, Germany.

Monoolein (Myverol 18-99, 98.1\% monoglycerides, Naarden, The Netherlands) gel was obtained in a 7:3 (Monoolein:Water) proportion as described before (Lara et al.). Briefly, monoolein was weighed and heated to $45^{\circ} \mathrm{C}$. Water in the same temperature was added and the mixture was left to rest until it became a transparent and viscous mass. BMP in water solution $(1 \mathrm{mg} / \mathrm{mL})$ was added and the mixture homogenized.

Chitosan (Hidagem HCMF, Cognis, Spain) gel was prepared at dispersing $8.3 \mathrm{mg}$ of chitosan in $1.0 \mathrm{~mL}$ of rhBMP2 water solution followed of acidifying with acetic acid (1.0\%).

Poloxamer 407 (Pluronicx F-127®) was purchased from BASF, Brazil.

Amounts of the gels sufficient to carry 1, 3 and $7 \mathrm{mg}$ of rhBMP-2 were applied in the critical bone defects.

Animals. Nine male Wistar rats $(n=9), 350 \mathrm{~g}$, were selected and allowed to acclimatize for one week prior to surgery. The animals were fed with commercial rat chow and had access to food and water ad libitum. A cylindrical critical bone defect $(6 \times 2 \mathrm{~mm})$ was created in the posterior portion, left side, on the calvarial bone and filled with animals' coagulum (Group 1), monoolein gel (Group 2), poloxamer gel (Group 3), monoolein gel $+1 \mu \mathrm{g}$ rhBMP-2 (Group 4), monoolein gel + $3 \mu \mathrm{g}$ rhBMP-2 (Group 5), monoolein gel $+7 \mu \mathrm{g}$ rhBMP-2 (Group 6), poloxamer gel $+1 \mu \mathrm{g} \operatorname{rhBMP}-2$ (Group 7), poloxamer gel $+3 \mu \mathrm{g}$ rhBMP-2 (Group 8), poloxamer gel + $7 \mu \mathrm{g}$ rhBMP-2 (Group 9).

Surgical procedure. The rats were anaesthetized with standard anesthetic cocktail consisting of ketamine hydrochloride $(60 \mathrm{mg} / \mathrm{Kg})$ and xylazine $(5 \mathrm{mg} / \mathrm{Kg})$, administered intraperitoneally. Surgery was performed using aseptic 
ISSA, M. J. P.; PETENUSCI, S. O.; SIÉSSERE, S.; REGALO, H. S. C.; LOPES, A. R.; DI MATTEO, S. M. A.; IYOMASA, M. M. \& DEFINO, A. H. L. Biochemical analysis by calcium determination on the newly formed bone in critical bone defects submitted to different treatments. A pilot study. Int. J. Morphol., 25(3):511-518, 2007.

techniques. A linear incision was made through the skin, and the osteotomy was performed using a high-speed drill, adjusted to $3000 \mathrm{rpm}$, and abundant irrigation.

Animals sacrifice. After two weeks, the animals were anaesthetized with urethane $37.5 \%(0.4 \mathrm{~mL} / 100 \mathrm{~g})$ and the calvarial bone samples were removed for biochemical analysis, calcium dosage analysis. The samples were inserted into individual beckers and weighed with the objective to determine the fresh weight of the samples (organic component + mineral component) and heated until $700^{\circ} \mathrm{C}$, for 15 hours to determine only the mineral compound. After balance determination, the mineral component was diluted in chloridric acid $1 \mathrm{~N}$ and the calcium dosage was determined by colorimetric method, using a photocolorimeter (Micronau, Brazil) and a comercial kit (Labtest Sistemas Diagnósticos Ltda, Belo Horizonte, Brazil).

\section{RESULTS}

Clinical observations. The postoperative process was considered normal, without infection or other complications.

Calcium dosage analysis. Considering the weight of the fresh bone samples, mineral plus organic components, it was obtained the following values ( $\mathrm{mg}$ ) for the nine groups, in sequence: $18.50 \mathrm{mg} ; 2.60 \mathrm{mg} ; 2.70 \mathrm{mg} ; 5.70 \mathrm{mg} ; 10.60$; 19.80mg; 10.60mg; 9.80mg; 5.90mg (Fig. 1).

Considering the calcined weight of the bone samples, mineral component, it was obtained the following values (mg) for the nine groups, in sequence: $6.50 \mathrm{mg} ; 1.40 \mathrm{mg}$; $5.40 \mathrm{mg} ; 4.30 \mathrm{mg} ; 7.10 \mathrm{mg} ; 13.30 \mathrm{mg} ; 8.10 \mathrm{mg} ; 11.20 \mathrm{mg}$; 16.50mg (Fig. 2).

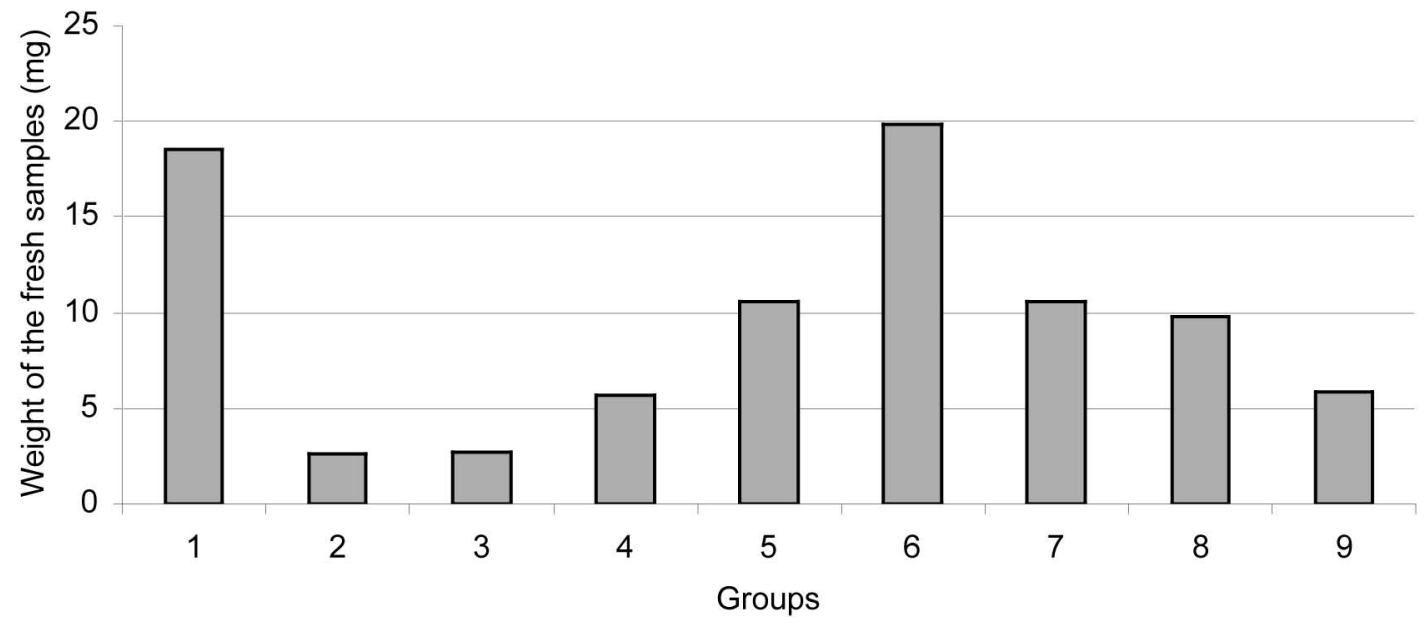

Fig. 1. Weight of the fresh bone samples $(\mathrm{mg})$ in the nine studied groups.

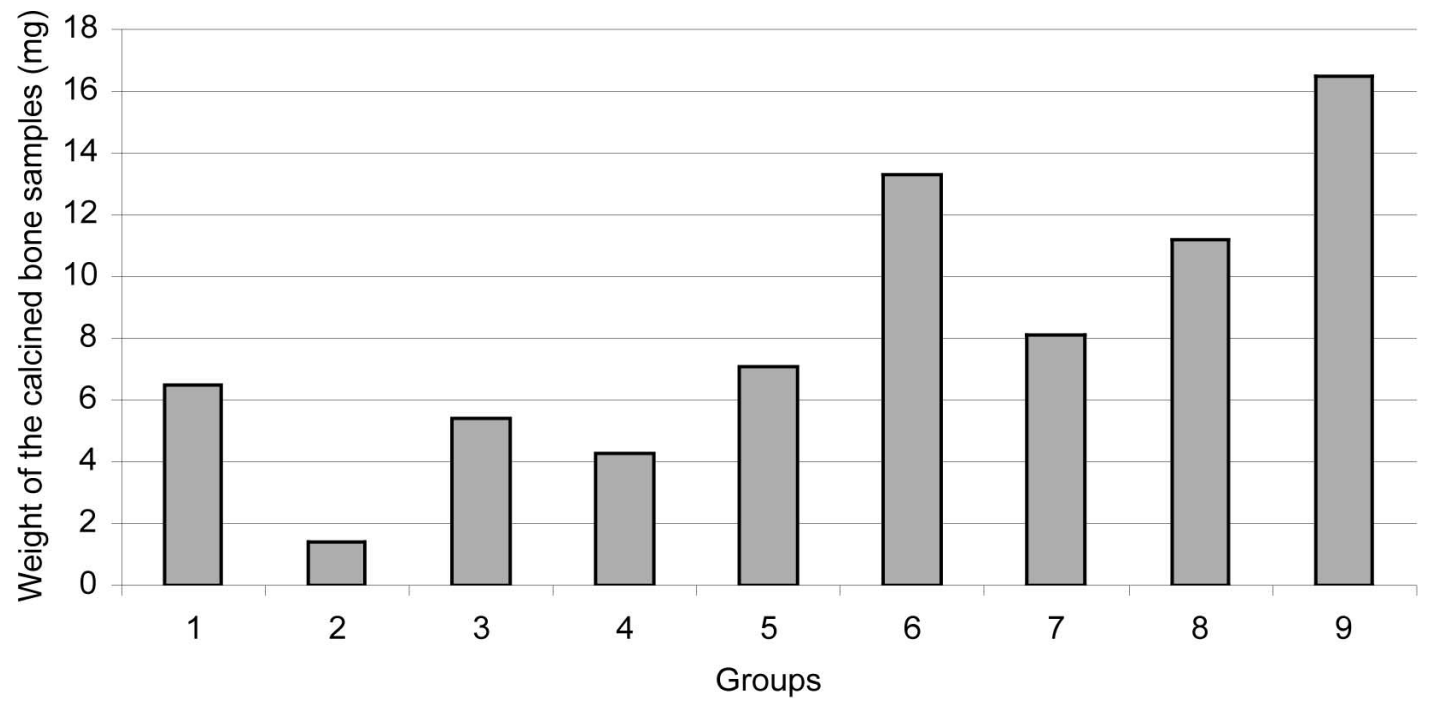

Fig. 2. Weight of the calcined bone samples $(\mathrm{mg})$ in the nine studied groups. 
ISSA, M. J. P.; PETENUSCI, S. O.; SIÉSSERE, S.; REGALO, H. S. C.; LOPES, A. R.; DI MATTEO, S. M. A.; IYOMASA, M. M. \& DEFINO, A. H. L. Biochemical analysis by calcium determination on the newly formed bone in critical bone defects submitted to different treatments. A pilot study. Int. J. Morphol., 25(3):511-518, 2007.

Considering the calcium dosage in the calcined bone samples, it was obtained the following values $(\mu \mathrm{g})$ for the nine groups, in sequence: $128.42 \mu \mathrm{g} ; 60.29 \mu \mathrm{g} ; 149.56 \mu \mathrm{g}$; $21.28 \mu \mathrm{g} ; 328.89 \mu \mathrm{g} ; 822.23 \mu \mathrm{g} ; 328.11 \mu \mathrm{g} ; 399.37 \mathrm{mg}$; $743.93 \mu \mathrm{g}$ (Fig. 3).
Considering the calcium dosage $(\mu \mathrm{g} / \mathrm{mg})$ of the calcined bone samples, it was obtained the following values $(\mu \mathrm{g})$ for the nine groups, in sequence: $7.78 \mathrm{mg} ; 43.06 \mu \mathrm{g} ; 27.69 \mu \mathrm{g} ; 4.95 \mu \mathrm{g}$; $46 ; 32 \mu \mathrm{g} ; 61.82 \mu \mathrm{g} ; 40.50 \mu \mathrm{g} ; 61.44 \mu \mathrm{g} ; 66.42 \mu \mathrm{g}$ (Fig. 4).

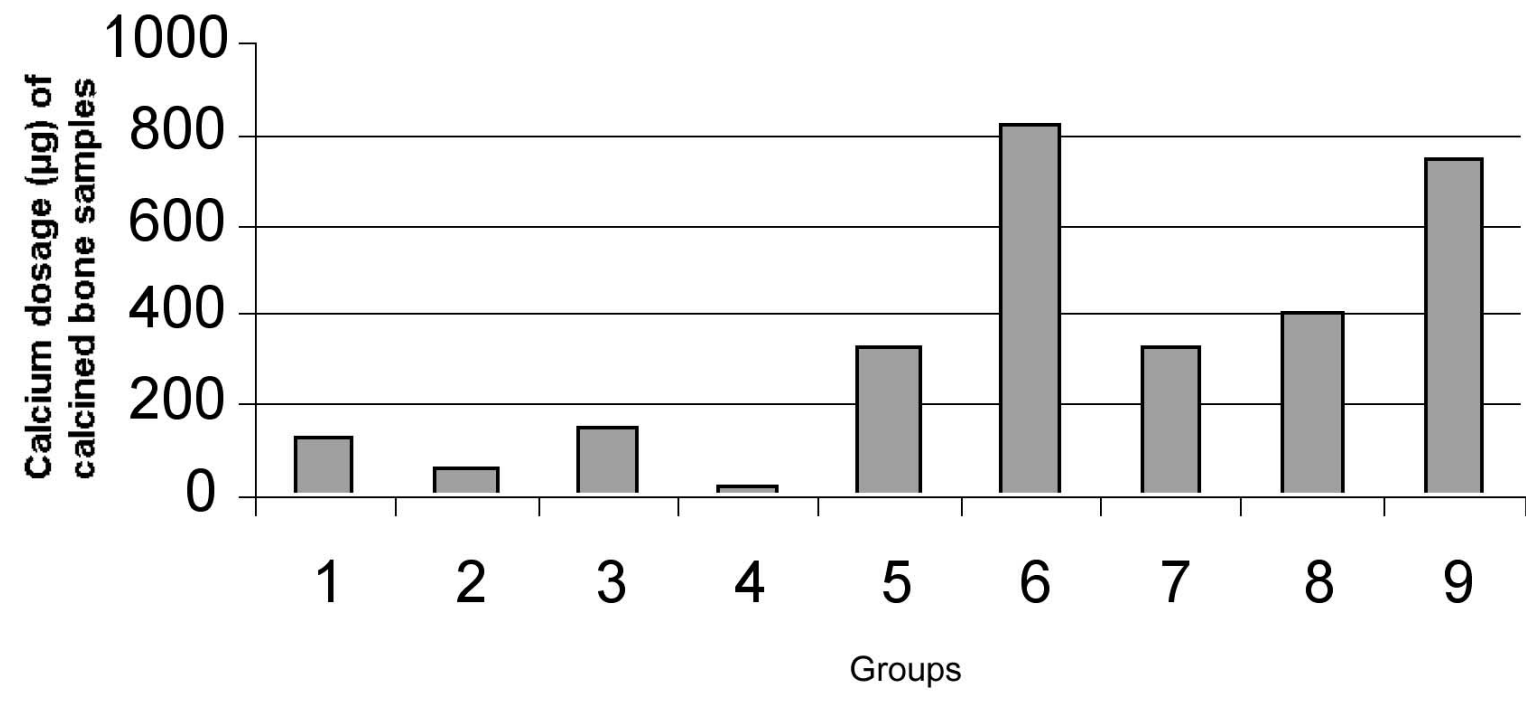

Fig. 3. Calcium dosage $(\mu \mathrm{g})$ of calcined bone samples in the nine studied groups.

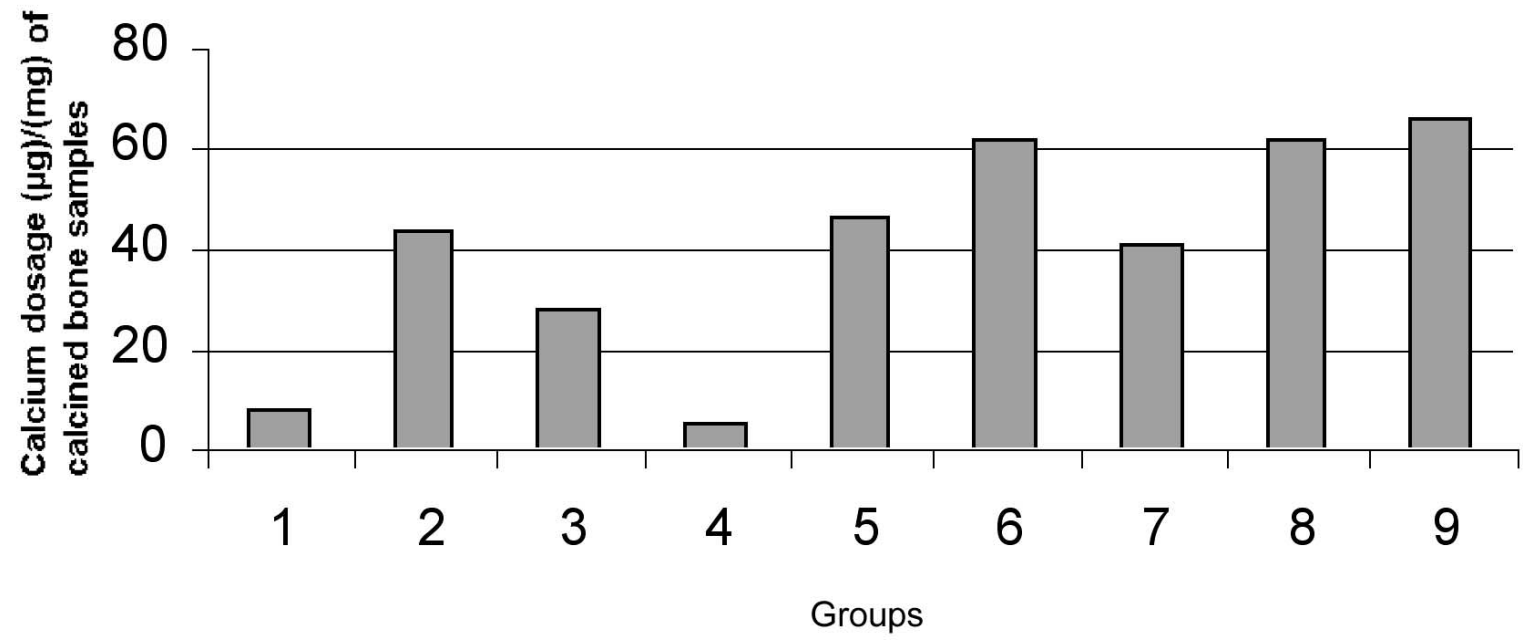

Fig. 4. Calcium dosage $(\mu \mathrm{g})$ by $(\mathrm{mg})$ of calcined bone samples in the nine studied groups. 
ISSA, M. J. P.; PETENUSCI, S. O.; SIÉSSERE, S.; REGALO, H. S. C.; LOPES, A. R.; DI MATTEO, S. M. A.; IYOMASA, M. M. \& DEFINO, A. H. L. Biochemical analysis by calcium determination on the newly formed bone in critical bone defects submitted to different treatments. A pilot study. Int. J. Morphol., 25(3):511-518, 2007.

\section{DISCUSSION}

The aim of this study was to evaluate the calcium dosage by biochemical analysis of the newly formed bone, in critical bone defects created on the calvarial tissue and filled with biomaterials combined or not with rhBMP-2 is different concentrations, in male Wistar rats. It was found in this study a straightly relationship between the newly formed bone, more expressed in the groups that the rhBMP-2 was applied in more quantities, and calcium dosage. Thus, the greatest values for calcium dosage were found when it was inserted $7 \mu \mathrm{g}$ rhBMP-2, independently of the gel carrier used. These results are interesting because they show that the newly formed bone is accompanied by biochemical alteration, represented by the mineralization of this tissue, calcium dosage analysis. Thus, it is possible to relate that besides the rhBMP-2 action to convert mesenchymal cells into osteoblastic and chondroblastic cells, osteoinduction process, the resultant tissue after its action is an organized bone, which it is interesting for clinical application in many fields of the Medical Sciences.

The Wistar rat experimental model used in this study is an excellent animal experimental model with some positive characteristics, a rapid healing period, animals easily lodged and fed, resistance to climatic variations, low cost, besides being routinely used in other experimental conditions involving bone reconstruction. The calvarial bone tissue was chosen to evaluate the bone repair because it shows favorable bone structure, trabecular and cortical bone, in addition, adequate volume to observe the healing bone process in sagittal, frontal and transversal planes.

The biomaterials used in this study, monoolein, chitosan and poloxamer gels, are already being used as sustained release media of several drugs and medicines including proteins and peptides (Geraghty et al., 1997; Nielsen et al., 1998; Lee and Kellaway, 2000b; Paavola et al., 2000; Lee et al., 2001; Bonacucina et al., 2005; Bhattarai et al., 2005; Kofuji et al., 2005 and Kao et al., 2006). The gels physical and chemical properties such as consistency, viscosity, biocompatibility to neighboring tissues are adequate for implantation, allowing rhBMP-2 to remain in situ and to adhere to the bone defect walls. Furthermore, they are of low cost and easily synthesized from carbohydrates and fats (Nylander et al., 1996; Geraghty et al.; Lee and Kellaway, 2000b; Shah et al., 2001; Lee et al., 2005 and Boyd et al., 2006).

The protein purity grade is an important factor directly influencing indexes of new bone formation. In this study, gel electrophoretic analysis followed by spectrophotometric determinations indicated that rhBMP-2 was highly pure, $86 \%$ of purity, explaining the large quantity of newly formed bone found in animal groups where it was applied and a positive correlation between these newly formed bone and calcium dosage analysis.

The effects of growth factor dose are intensely investigated not only in terms of efficiency but also cost. In this study bone defects with $6 \times 2 \mathrm{~mm}$ were treated with 1,3 and $7 u$ g of rhBMP-2 during 2 weeks before animals sacrifice and analysis. Other authors, like Yasko et al., 1992, reported bone regeneration after creation a critical bone defect with $5 \mathrm{~mm}$ of extension in rat femurs and insertion of $11 \mathrm{ug}$ rhBMP-2, by mechanical, radiographic and histological evidence while a much smaller dose, 1.4ug rhBMP-2, produced new bone tissue, but not sufficient to close the defect. Higher dosages, as 20mg of rhBMP-2 applied to supra-alveolar bone defects, $5 \mathrm{~mm}$ of height, in Beagle dogs showed substantial bone regeneration after 8 weeks (Sigurdsson et al., 1995). On the other hand, extremely high dosages as $50 \mu \mathrm{g}$ rhBMP-2 combined with collagen matrix and applied to $4 \mathrm{~mm}$ defects in rat skulls were capable to produce new bone formation (Inoda et al., 2004), but did not show advantages in relation to smaller and sustained release dosages as shown by Wang et al. (1990) who tested 0.5 to $115 \mu \mathrm{g}$ dosages of rhBMP-2.

The results of this study showed a positive correlation between the calcium dosage analysis and the newly formed bone.

ISSA, M. J. P.; PETENUSCI, S. O.; SIÉSSERE, S.; REGALO, H. S. C.; LOPES, A. R.; DI MATTEO, S. M. A.; IYOMASA, M. M. \& DEFINO, A. H. L. Análisis bioquímico para la determinación de calcio en hueso neoformado con defectos críticos sometidos a diferentes tratamientos. Estudio piloto. Int. J. Morphol., 25(3):511-518, 2007.

RESUMEN: El propósito de este estudio fue evaluar el contenido de calcio del hueso neoformado, en defectos óseos críticos provocados en la bóveda craneana y rellenados con diferentes substancias, en ratas Wistar machos. Un defecto crítico cilíndrico (6x2mm) fue provocado en el lado izquierdo de la porción posterior del hueso de la bóveda craneana, en nueve animales y rellenado con coágulo sanguíneo del propio animal, gel de monoleina, gel de poloxamer, gel de monoleina $+1 \mu \mathrm{g}$ de rhBMP-2, gel de monoleina $+3 \mu \mathrm{g}$ rhBMP2 , gel de monoleina $+7 \mu \mathrm{g}$ rhBMP-2, gel de poloxamer $+1 \mu \mathrm{g}$ rhBMP-2, gel de poloxamer $+3 \mu \mathrm{g}$ rhBMP-2, gel de poloxamer $+7 \mu \mathrm{g}$ rhBMP-2. Los resultados de este estudio mostraron una correlación positiva entre el contenido de calcio y el hueso neoformado.

PALABRAS CLAVE: Reparación ósea; Biomateriales; rhBMP-2; Transportadores; Calcio. 
ISSA, M. J. P.; PETENUSCI, S. O.; SIÉSSERE, S.; REGALO, H. S. C.; LOPES, A. R.; DI MATTEO, S. M. A.; IYOMASA, M. M. \& DEFINO, A. H. L. Biochemical analysis by calcium determination on the newly formed bone in critical bone defects submitted to different treatments. A pilot study. Int. J. Morphol., 25(3):511-518, 2007.

\section{REFERENCES}

Bhattarai, N.; Ramay, H. R.; Gunn, J.; Matsen, F. A. \& Zhang, M. PEG-grafted chitosan as an injectable thermosensitive hydrogel for sustained protein release. J. Control. Release., 103:609-24, 2005.

Bohorquez, M.; Kock, C.; Tryastad, T. \& Pandit, N. A study of the temperature-dependent micellization of Pluronic F-127. J. Colloid. Interf. Sci., 216:34-40, 1999.

Bonacucina, G.; Palmieri, G. F. \& Craig, D. Q. Rheological and dielectric characterization of monoolein/water mesophases in the presence of a peptide drug. J. Pharm. Sci., 94:2452-62, 2005.

Boyd, B. J.; Whittaker, D.V.; Khoo, S. M. \& Davey, G. Lyotropic liquid crystalline phases formed from glycerate surfactants as sustained release drug delivery systems. Int. J. Pharm., 309:218-26, 2006.

Ganem-Quintanar, A.; Quintanar-Guerrero, D. \& Buri, P. Monoolein: a review of the pharmaceutical applications. Drug. Dev. Ind. Pharm., 26:809-20, 2000.

Geraghty, P. G.; Attwood, D.; Collett, J. H.; Sharma H. \& Dandiker, Y. An investigation of the parameters influencing the bioadhesive properties of Myverol 1899/water gels. Biomaterials, 18:63-7, 1997.

Hejazi, R. \& Amiji, M. Chitosan-based gastrointestinal delivery systems. J. Control. Release, 89:151-65, 2003.

Hogan, B.L. Bone morphogenetic proteins in development. Curr. Opin. Genet. Dev., 6:432-8, 1996.

Inoda, H.; Yamamoto, G. \& Hattori, T. Histological investigation of osteoinductive properties of rhBMP-2 in a rat calvarial bone defect model. J. Craniomaxillofac. Surg., 32:365-9, 2004.

Johnston, T. P. \& Miller, S. C. Toxicological evaluation of Poloxamer vehicle for intramuscular use. J. Parent. Sci. Technol., 39:230-41, 1985.

Kao, H. J.; Lin, H. R.; Lo, Y. L. \& Yu, S. P. Characterization of pilocarpine-loaded chitosan/Carbopol nanoparticles. J. Pharm. Pharmacol., 58:179-86, 2006.

Kim, H. D. \& Valentini, R. F. Retention and activity of BMP2 in hyaluronic acid-based scaffolds in vitro. J. Biomed. Mater. Res., 59:573-84, 2002.
Kofuji, K.; Murata, Y. \& Kawashima, S. Sustained insulin release with biodegradation of chitosan gel beads prepared by copper ions. Int. J. Pharmacol., 303:95-103, 2005.

Kuboki, Y.; Jin, Q. \& Takita, H. Geometry of carriers controlling phenotypic expression in BMP-induced osteogenesis and chondrogenesis. J. Bone. Joint. Surg. Am., 83A (Suppl 1):S105-S15, 2001.

Lara, M. G.; Bentley, M.V. L. B. \& Collett, J. H. In vitro drug release mechanism and drug loading studies of cubic phase gels. Int. J. Pharm., 293:241-50, 2005.

Lee, J. \& Kellaway, I.W. Buccal permeation of [D-Ala2, DLeu5] enkephalin from liquid crystalline phases of glyceryl monooleate. Int. J. Pharm., 195:35-8, 2000a.

Lee, J. \& Kellaway, I.W. Combined effect of oleic acid and polyethylene glycol 200 on buccal permeation of [DAla2, D-Leu5] enkephalin from a cubic phase of glyceryl monooleate. Int. J. Pharm., 204:137-44, 2000b.

Lee, J.; Young, S. A. \& Kellaway, I.W. Water quantitatively induces the mucoadhesion of liquid crystalline phases of glyceryl monoleate. J. Pharm. Pharmacol., 53:62936, 2001.

Lee, S. J.; Kim, S. W.; Chung, H.; Park, Y.T.; Choi, Y. W.; Choi, Y. W.; Cho, Y. H. \& Yoon, M. S. Bioadhesive drug delivery system using glyceryl monooleate for the intravesical administration of paclitaxel. Chemotherapy, 51:311-8, 2005.

Mahmood, J.; Takita, H.; Ojima, Y.; Kobayashi, M.; Kohgo, T. \& Kuboki, Y. Geometric effect of matrix upon cell differentiation: BMP-induced osteogenesis using a new bioglass with a feasible structure. J. Biochem., 129:16371, 2001.

Mi, F. L.; Tan, Y. C.; Liang, H. C. \& Sung, H.W. In vitro biocompatibility and degradation of a novel injectablechitosan-based implant. Biomaterials, 23:181-91, 2002.

Moore, T.; Croy, S.; Mallapragada, S. \& Pandit, N. Experimental investigation and mathematical modeling of Pluronic F-127 gel dissolution: drug release in stirred system. J. Control. Release, 67:191-202, 2000.

Nielsen, L. S.; Schubert, L. \& Hansen, J. Bioadhesive drug 
ISSA, M. J. P.; PETENUSCI, S. O.; SIÉSSERE, S.; REGALO, H. S. C.; LOPES, A. R.; DI MATTEO, S. M. A.; IYOMASA, M. M. \& DEFINO, A. H. L. Biochemical analysis by calcium determination on the newly formed bone in critical bone defects submitted to different treatments. A pilot study. Int. J. Morphol., 25(3):511-518, 2007.

delivery systems. I. Characterization of muco adhesive properties of systems based on glyceryl monooleate and glyceryl monolinoleate. Eur. J. Pharm. Sci., 6:231-9, 1998.

Nylander, T.; Mattisson, C.; Razumas, V.; Miezis, Y. \& Hakansson, B. A study of entrapped enzyme stability and substrate diffusion in a monglyceride-based cubic liquid crystalline phase. J. Colloid. Interface. Sci., 114: 311-20, 1996.

Paavola, A.; Kilpelaine, I.; Yliruusi, J. \& Rosenberg, P. Controlled release injectable liposomal gel of ibuprofen for epidural analgesia. Int. J. Pharm., 199:85-93, 2000.

Park, H. \& Park, K. Biocompatibility issues of implantable drug delivery. Pharm. Res., 13:1770-6, 1996.

Reddi, A. H. Bone morphogenetic proteins: an unconventional approach to isolation of first mammalian morphogens. Cytokine Growth Factor Rev., 8:11-20, 1997.

Reddi, A. H. Role of morphogenetic proteins in skeletal tissue engineering and regeneration. Nature. Biotechnol., 16: 247-52, 1998.

Ruhe, P. Q.; Hedberg, E. L.; Padron, N. T.; Spauwen, P. H.; Jansen, J. A. \& Mikos, A. G. rhBMP-2 release from injectablepoly(DL-lactic-co-glycolic acid)/calciumphosphate cement composites. J. Bone. Joint. Surg. Am. 85A(Suppl 3):75-81, 2003.

Rutherford, R. B. \& Gu, K. Treatment of inflamed ferret dental pulps with recombinant bone morphogenetic protein-7. Eur. J. Oral. Sci., 108:202-6, 2000.

Saad, B.; Kuboki, Y.; Welti, M.; Uhlschmid, G.K.; Neuenschwander, P. \& Suter, U.W. DegraPol-foam: A degradable and highly porous polyesterurethane foam as a new substrate for bone formation. Artif. Organs, 24:939-45, 2000.

Schmolka, I.V. Artificial skin. I. Preparation and properties of pluronic F-127 gels of treatment of burns. J. Biomed. Mater. Res., 6:571-82, 1972.

Shah, J. C.; Dadhale, Y. \& Chilukuri, D. M. Cubic phase gels as drug delivery systems. Adv. Drug. Deliv. Rev., 47:229-50, 2001.

Sigurdsson, T. J.; Lee, M. B.; Kubota, K.; Turek, T. J.; Wozney, J. M. \& Wikesjo, U. M. Periodontal repair in dogs: Recombinant human bone morphogenetic protein2 significantly enhances periodontal regeneration. $J$. Periodontol., 66:131-8, 1995.

Turchiello, R. F.; Vena, F. C. B.; Maillard, P. H.; Souza, C. S.; Bentley, M. V. L. B. \& Tedesco, A. C. Cubic phase gel as a drug delivery system for topical application of 5-ALA, its ester derivatives and m-THPC in photodynamic therapy (PDT). Photochem. Photobiol., 70:1-6, 2003.

Uludag, H.; Friess, W.; Williams, D.; Porter, T.; Timony, G.; D'Augusta, D.; Blake, C.; Palmer, R.; Biron, B. \& Wozney, J. rhBMP-collagen sponges as osteoinductive devices: Effects of in vitro sponge characteristics and protein $\mathrm{pI}$ on in vivo rhBMP pharmacokinetics. Ann. NY. Acad. Sci., 875:369-78, 1999.

Uludag, H.; Gao, T.; Porter, T. J.; Friess, W. \& Wozney, J.M. Delivery systems for BMPs: Factors contributing to protein retention at an application site. J. Bone. Joint. Surg. Am., 83A (Suppl 1):S128-S35, 2001.

Vehof, J.W.; Fisher, J. P.; Dean, D.; van der Waerden, J. P.; Spauwen, P. H.; Mikos, A.G. \& Jansen, J. A. Bone formation in transforming growth factor -1-coated porous poly(propylene fumarate) scaffolds. J. Biomed. Mater. Res., 60:241-51, 2002.

Veyries, M. L.; Couarraze, G.; Geiger, S.; Agnely, F.; Massias, L.; Kunzli, B.; Faurisson, F. \& Rouveix B. Controlled release of vancomycin from Poloxamer 407 gels. Int. J. Pharm., 192:183-93, 1999.

Wang, E. A.; Rosen, V.; D'Alessandro, J. S.; Bauduy, M.; Cordes, P.; Harada, T.; Israel, D. I.; Hewick, R .M.; Kerns, K. M.; LaPan, P.; Luxenberg, D. P.; Mc Quaid, D.; Moutsatsos, I. K.; Nove, J. \& Wozney, J. M. Recombinant human bone morphogenetic protein induces bone formation. Proc. Nat. Acad. Sci. USA., 87: 2220-4, 1990.

Whang, K.; Tsai, D. C.; Nam, E. K.; Aitken, M.; Sprague, S. M.; Patel, P. K. \& Healy, K. E. Ectopic bone formation via rhBMP-2 delivery from porous bioabsorbable polymer scaffolds. J. Biomed. Mater. Res., 42: 491-9, 1998.

Winn, S.R.; Uludag, H. \& Hollinger, J. O. Carrier systems for bone morphogenetic proteins. Clin. Orthop., 357: S95-S106, 1999.

Wozney, J. M. \& Rosen, V. Bone morphogenetic protein and bone morphogenetic protein gene family in bone formation and repair. Clin. Orthop., 346:26-37, 1998. 
ISSA, M. J. P.; PETENUSCI, S. O.; SIÉSSERE, S.; REGALO, H. S. C.; LOPES, A. R.; DI MATTEO, S. M. A.; IYOMASA, M. M. \& DEFINO, A. H. L. Biochemical analysis by calcium determination on the newly formed bone in critical bone defects submitted to different treatments. A pilot study. Int. J. Morphol., 25(3):511-518, 2007.

Yang, X.; Tare, R. S.; Partridge, K. A.; Roach, H. I.; Clarke, N. M.; Howdle, S. M.; Shakesheff, K. M. \& Oreffo, R. O. Induction of human osteoprogenitor chemotaxis, proliferation, differentiation, and bone formation by osteoblast stimulating factor-1/pleiotrophin: Osteoconductive biomimetic scaffolds for tissue engineering. J. Bone. Miner. Res., 18:47-57, 2003.

Yasko, A.W.; Lane, J. M.; Fellinger, E. J.; Rosen, V.; Wozney, J. M. \& Wang, E. A. The healing of segmental bone defects, induced by recombinant human bone morphogenetic protein (rhBMP-2). A radiographic, histological and biomechanical study in rats. J. Bone. Joint Surg., 74:659-71, 1992.

Ziegler, J.; Mayr-Wohlfart, U.; Kessler, S.; Breitig, D. \& Gunther, K. P. Adsorption and release properties of growth factors from biodegradable implants. J. Biomed. Mater. Res., 59:422-8, 2002.
Correspondence to:

Dr. João Paulo Mardegan Issa

Faculdade de Odontologia de Ribeirão Preto - USP

Departamento de Morfologia, Estomatologia e Fisiologia Av. Café S/N

CEP: $14040-904$

Ribeirão Preto, SP, BRAZIL

Phone: +55-16-36024095 Fax: +55-16-36330999

E-mail: jpmissa@forp.usp.br

Received: 15-03-2007

Accepted: 22-06-2007 